\title{
An Environmental Sustainability-Based Ecopreneurship Learning Process
}

\author{
Herlina $^{1 *}$ Disman $^{2}$ Sapriya $^{2}$ Nana Supriatna ${ }^{2}$ \\ ${ }^{I}$ Management Department, Kridatama Bandung University of Economic, Bandung, Indonesia \\ ${ }^{2}$ School of Post Graduate Studies Universitas Pendidikan Indonesia, Bandung, Indonesia \\ *Corresponding author.Email: herlina@upi.edu
}

\begin{abstract}
Considering a significant increase in number of young entrepreneurs, this study was attempted to identify students' role in an ecopreneurship-based social science learning in order maintain environmental sustainability. This is a qualitative study using a case study approach. This study revealed that the ecopreneruship learning conducted in university environment was not significantly effective since not all of students experienced the real context through field study. They only focused on classroom learning and did not have interest to initiate and develop an environmental-based enterprise. The eminence of the implementation of this learning process in this study was the emergence of students' awareness, intention, and action to learn about environmental-based enterprise. This study also recommends a cooperation between university and ecopreneurs so that the students can directly and comprehensively learn and practice or even build an enterprise without neglecting their environmental sustainability for the economic growth.
\end{abstract}

Keywords: Ecopreneurship learning, environmental sustainabiltiy, entreprenership sustainability, economic growth.

\section{INTRODUCTION}

The main problem motivating this study was the lack of enterpreneurs' awareness in preserving environment. Media and academicians have progressively debated on the environmental issues [1]. Among academicians, the concern regarding this issue was reflected on the emergence of ecopreneurship [2] and on the study of the implementation of enterpreneurial ecosystem litarure related to sustainable development [3]. Another study focusing on environmental entrepreneurship was also study about raising and developing entrepreneurship $[4,5,6]$. In the last decade, several research findings focusing on the relation between enterpreneuship with environmental preservation pictured how education and environmental movement in the form of role model and massive environmental damage significantly influenced the formation of the environment and entrepreneurial habits [7]. In education, students were introduced to multidiscurcive construction that is an enterpreneurial sustainablity with various conflicts [8]. In the past few years, study regarding environmental sustainability has not grabbed people attention greatly; yet, recently, research on environmental entrepreneurs specifically its difference from conventional entrepreneurs and public has emerged progressively [9]. A call for further research that integrates practical theory with entrepreneurship study keeps increasing [10], in order to identify the highly expected implementation of "practical theory". He assumed that "entrepreneurial practice is a human activity usually socially located and organized where entrepreneurial practitioners manifest their specific skills and utilize special tools' [10]. Based upon this, this study was aimed at identifying learning aspects and practices in the field of the academicians' environment especially in Social Science Education study program and in the field of the entrepreneurs 'experiences with environmental sustainability. It is expected that students as the candidates of young entrepreneurs intending to engage in entrepreneurship to be aware of environmental sustainability and economic growth.

\section{THEORETICAL FRAMEWORK 2.1 Ecopreneurship}

Ecopreneurship is well-known as entrepreneurial activities in which the enterprise is strived to maintain and preserve environment. Young entrepreneurs are expected to contribute to the transformation of a more sustainable society through innovation they make [7]. In Indonesia, most of the enterprises built and developed have not completely balanced the efforts to deal with the waste of their business. This phenomenon can be found easily and widely in this country. In the UK, the number of popular entrepreneurs have successfully become innovative entrepreneurs who extremely concerned on the environmental issues [11]. (Macalister, 2004). In addition, the image of ecopreneurship itself is an ecological paradigm of modernization that became increasingly important in environmental policies and practices in industrialized countries [12 \&13]. Other industries initiate "reforestation" to meet the demand of health products and services, and this phenomenon shows the success of ecopreneurship [14]. Several famous entrepreneurs paying attention to environmental issues in their business such as Anita 
Roddick from The Bod Shop and Ben Cohen and Jerry Greenfield from Ben and Jerry's have involved in modernizing the environment [15\&16].

\subsection{Ecopreneurship Learning}

Ecopreneurship learning in educational environment is still not optimally and comprehensively implemented. Schools and universities provide entrepreneurship education to be studied in general concept. In the university level, especially in Social Science Education study program, ecopreneurship learning is not specifically offered in form of a subject to be studied in each semester but it explicitly became part of the entrepreneurship course. The ecopreneurship study was conducted by students by examining the examples of environmental-based entrepreneurs via internet, or by those who have accidently seen or communicated with entrepreneurs being involved in environmental sustainability. By publishing and spreading the results of the study through internet, students can easily access material related to environment-based entrepreneurship. However, students do not immediately observe and concern on the impact of $\mathrm{n}$ entrepreneurship especially its impact on environment. In this study, ecopreneurship learning could create empirical learning that enabled students to visit business establishments in areas close to their campus. Moreover, they could also observe and analyze learning outcomes outside the classroom and created learning resources in the classroom that they would share comprehensively. Here is the scheme of ecopreneurship learning design (Figure1):

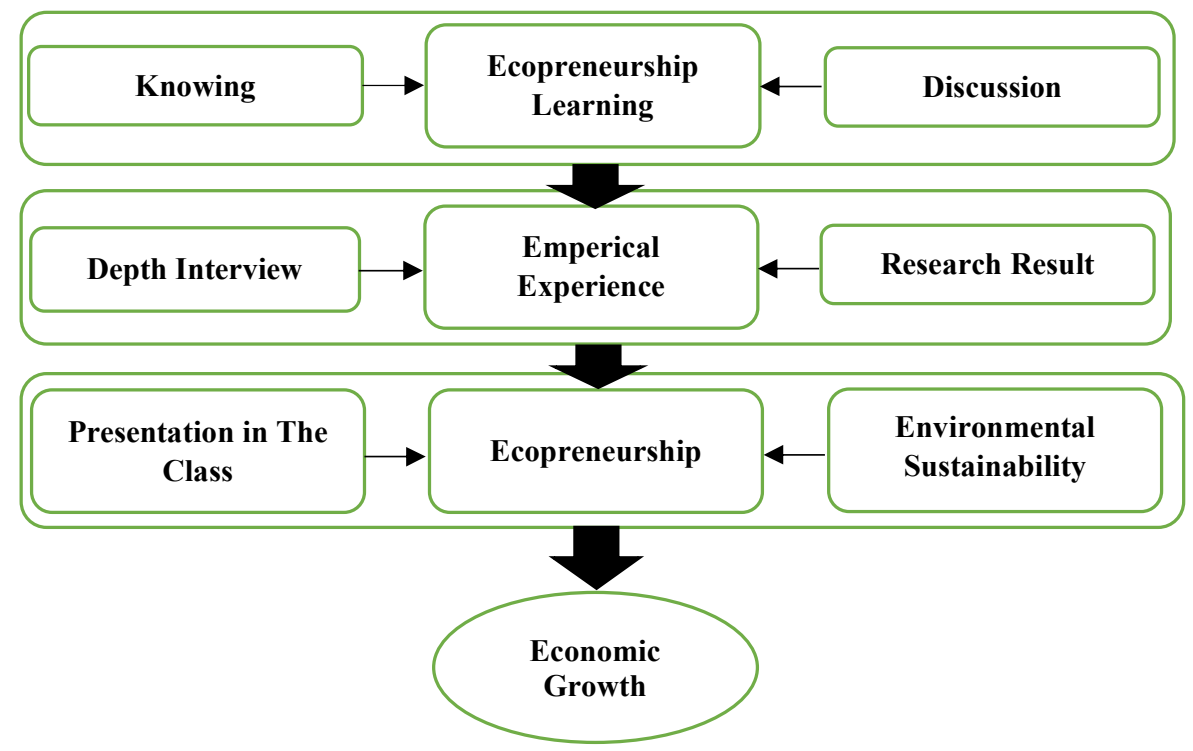

Figure 1 The process of Ecopreneurship Learning

\subsection{Environmental Sustainability}

Environmental sustainability is extremely important for community survival. According to Santilo 2007 [17], there are 2 pillars of sustainable development, one of which is the ecological sustainability development considering the limited natural resources and ecosystems [17]. And, economy is a major cause of environmental problems by Johnston et al., 2007 [17]. However, in preserving the environment, development also keeps reducing the exploitation of valuable natural resources and ecosystems $[18,19]$. In relation with the operation of a business or company that still pays attention to environmental sustainability, a good goal of business development is to minimize the use of chemicals and reduce pollution [19]. The goals of a business or enterprise emphasizing environmental sustainability will be a strategy to compete with other competitors through internally developing competitive strength and externally involving in environmental sustainability issue [20]. Developing and implementing environmental strategy is also supported [21]. Meanwhile, referring to other researchers, there are four components in survival, namely regulation, public attention, expected competitive eminence, and top management commitment $[21,22,23]$.

\subsection{Ecopreneurship Environmental Sustainability}

Jolink and Niesten classified entrepreneurs based on three components covering environmental sustainability, the goals and how they create economic values [24]. Meanwhile, [25] categorized three characters of entrepreneurs based on environmental sustainability, namely, "those who aims at transforming the world", "those who speculate it as a media to earn money" and "those who speculate that the aim is merely to earn money". Based upon these, it can be said that each entrepreneur has his or her own goal(s). One of the competitive eminences in 
entrepreneurship sustainability is those who use their entrepreneurial strategies to create profit opportunities and values for individuals, organizations and communities. Therefore, an enterprise that considers environmental sustainability simultaneously explores new opportunities that underpin the entity's ability to create values across time [26]. Other entrepreneurs are expected to be sensitive, aware and to incorporate the aspects of environmental sustainability into their enterprise. Entrepreneurial startups based on environmental sustainability will build enterprise strategies by raising environmental issues and reversing strategies for the creation of environmental sustainabilitybased entrepreneurship which is believed to generate profits by directing their purchases, production, and marketing in environmental sustainability in order to achieve competitive eminences and strengths. Grounded on the various studies presented above, to sum up, Environmental Sustainabilitybased Ecopreneurship is a sustainable environmental entrepreneurship which is a process of identifying, evaluating and framing entrepreneurial opportunities that minimizes the impact of business on the natural nvironment and will give benefits for the community as a whole local community" by Gast [25].

\subsection{Economic Growth}

Even though entrepreneurship has significantly contributed to economic growth and development [27], market failures also relate with the less secure environmental implications [28]. In this context, academicians in the university level emphasize to play an active role in balancing economic goals with environmental sustainability goals [29 \& 4]. A strictly focused economic growth, sometimes, ignores the impact of the growth where entrepreneurship develops but it is not balanced with environmental sustainability; so, in this case, ecological sustainable entrepreneurs are demanded [17]. The relations between entrepreneurship, environment, and sustainable development and economic growth has been presented in the literatures studied by different paradigms trough different study approaches [17]. The studies are different because of different names and themes, including "ecopreneurship" [30,31], "environmental entrepreneurship/enviropreneurship" [32]. "Green entrepreneurship" [33], and "sustainable entrepreneurship" [4]. Yet, all of these different names reflect the same thing, namely creating entrepreneurship based on environmental sustainability which ultimately aims for economic growth.

\section{METHOD}

This is a participatory research, a research in which the researchers actively involved and contributed both in form of ideas and energy in order to conduct learning activities, specifically this ecopreneurship learning. As a consequence, the researchers were demanded to analyses their needs, set their goals and monitor as well as evaluate their own performance. For the service given to the students, in this participatory research, it would be developed in the site of the study [34]. This innovative participatory method was adopted into ecopreneurship learning as an example of practicing the theoretical concept on the topic of participation as stated [35,36].

Regarding learning process, the participants of this study were a group of objects or subjects used as the data sources, namely people, things and documents. The objects of this study were students of Social Science Education Study Program at Indonesia University of Education. Next, the students were engaged in ecopreneurship learning process both inside and outside classroom. For learning outside the classroom, they were encouraged to learn empirical experience in a company or enterprise. Parties of this study included 1) the leaders of the university; 2) the local government; and 3) the entrepreneurs. The involvement of the university leaders was in form of a permission given to students to visit selected locations for research and development. For the entrepreneurs, they were engaged to be interviewed regarding their role as the entrepreneurs who played an important role in economic growth in their region and who took a part in treating industrial waste.

The company or the location of the enterprise that would be selected as the site to study ecopreneurship learning by students was leather industry centre that produces jackets, bags, wallets and other things made of leather. The industry centre selected was Leather Industry Centre Sukaregang located in Garut, East Java. This site was selected in order to provide various experiences of ecopreneurship for students as the candidate of talented young ecopreneurs.

The students, as the objects of this study, included students from 4 classes (each class consisted of 3 students) from semester 3 to semester 6 . The total number of the students were 12 average 19 year old students consisting of 6 male students and 6 female students. The number of enterprenuers in the leather industry interviewed by students were 12 persons consisting of 9 male enterpreneurs and 3 female entrepreneurs with background of education ranged from elementary to bachelor level.

Before starting the study, researchers prepared and designed relevant questions in line with the research instrument in order to help them identify the questions addressed to students. To achieve the goals of this study, the referent instruments consisting of a number 1 questions were developed based on the topic and questions of this research. The instrument was categorized into five themes as follows.

\subsection{Data Collection and Analysis}

Data collection was accomplished through two stages: firstly, students collected the data in campus; and, secondly, students collected data in the central industry. The data were collected through interview, observation, and document in Bahasa Indonesia and conducted to both students and entrepreneurs. Interview was carried out twice. The first interview was conducted in the classroom to discover how ecopreneurship learning was implemented and, another interview was conducted in the leather industry centre to reveal knowledge and experience regarding the enterprise and its contribution to society and environment. This study was accomplished for three months: 1 month for the data collection in the classroom and 2 months for the data collection in the Leather Industry Centre. Each data 
collection stage took from 2 to 2.5 hours. It was specifically conducted when the students of the Social Sciences Education study program carried out entrepreneurship learning, meaning that in one month the researcher could collect the data for 4 times. For data collection in the industrial centers, it took a longer time because the location was quite far (about 2 hours from campus). So, the data collection was conducted for 2 weeks and accomplished in 2 months (4 time-visits)

After being collected, the data were categorized based on the themes; while the useless data were reduced. Data in form of documentation gathered through recording could not be analyzed effectively and comprehensively because the data were collected in the side of the road so that the recordings were not clear. Fortunately, all of the students doing interview made a note regarding the interview result. Next, the data collected were interpreted meaningfully by referring to the relevant literatures with the problem of the study. After that, researchers asked the students to check and recheck the data that were interpreted to reach the validity and reliability. All data were interpreted bilingually both in Bahasa Indonesia and English.

\section{RESULT AND DISCUSSION}

The results of observations on the ecopreneurship learning process in the classroom in the university environment showed a learning routine that had not been able to foster students' interest to learn and initiate environment-based entrepreneurship. The introduction to ecopreneurship that had been given by the lecturers had not fully touched students' hearts and minds. This finding was reflected in the phenomenon where some students with small businesses had not opened businesses based on environmental sustainability. The provision of material in the classroom was merely focused on students' knowledge and understanding of environmental-based entrepreneurship. The learning process had not been presented in practical stage or in the implementation of ecopreneurship itself. The examples given were gathered from the internet, meaning that students could not observe the real examples of how the ecopreneurship process and its benefits and disadvantages were. So, this finding had an impact on the limitations of students' insights which were only limited to the knowledge and understanding.

Workshop activities or student visits to leather industry center provided empirical experiences. They could immediately see how the existence of the industrial center was, so, they could find out the origin of the leather industry center. Furthermore, students also know the types of products made from sheep skin as well as the manufacturing process. Some businessmen started their careers from their life experience in their hometown which was located at an altitude affecting the air condition there, which was a relatively cooler compared to other areas. By this geographical reason, entrepreneurs created ideas by making jackets to protect themselves from cold. The jacket was made of sheepskin because it was easy to find sheep in Garut, West Java. Many sheep breeders in this region deliberately supplied the sheepskin to meet the demands of the leather entrepreneurs. Thus, the sheepskin marketing could run smoothly. Basically, this leather industry contributed to the sheep farmer community because the basic ingredients for making leather jackets and others products made of sheepskin.

The leather industry that had progressively developed from year to year, had increased job opportunities for society such as work opportunities in sheep farms, leather craftsmen, jacket production, marketing, and even a parking section for visitors. The educational background of the employees in the leather business was from Elementary School to Bachelor degree. The most needed component in running expertise is skills and it is not merely about the level of education. Thus, the Human Resources in the area were absorbed, empowered and utilized.

Environmental sustainability in the leather industry area still needs to be concerned on. In interviews with businessmen, students found that leather craftsmen or entrepreneurs were more focused on good leather production without paying attention to the waste of the industry. The area eventually became an area that actually generated a lot of income both from the perspective of personal, community, and even regional income and was able to reduce unemployment, however, on the other hand, it had a negative impact on the environment. The waste caused the air pollution in the area to not be as fresh as it used to be. The waste produced from this business was not treated before being disposed to areas behind the location. This causes bad smell and air pollution. Bad quality irrigation was caused by the waste that was not processed properly. This condition has grabbed the attention of local government because of two contradictory things, the leather industry center which boosts the economic conditions of the area and at the same time produces waste that causes environmental issue for the local people. So, the environmental sustainability in the leather industry center has not been managed properly.

Another fundamental thing that students explored from the leather industry entrepreneurs in Garut, West Java was about a sustainable entrepreneurship, which was basically a manifestation of sustainable innovation aimed for the mass market and to provide benefits to the majority of society by manifesting sustainable innovation. It is similar to Gast et al. [25] who views sustainable entrepreneurship as "the process of identifying, evaluating and seizing entrepreneurial opportunities that reduce the impact of businesses on the natural environment and give benefits to global society and local communities". So this interpretation is also in line with recent research finding that specific market failures were the root causes underlying entrepreneurial activities aimed at realizing social goals as well as environmental improvements [28].

Furthermore, in terms of economic growth, students discovered the results of interviews conducted to entrepreneurs indicating that the economic growth in this area was significantly developing because the sales in the leather industry center was extremely profitable and even some products were exported abroad. The local government was also aware of this phenomenon, regional income also increased because of this commodity. Sales transaction 
increases sharply every day due to the innovation of these entrepreneurs in producing leather products with higher quality and varied by adjusting the current models. The impact of the enterprise could also be felt by the community, namely those who worked in the leather enterprise so that the number of unemployment could be reduced and other businesses could increase along with the cooperation between them, namely leather entrepreneurs and businessmen.

The activities conducted by students in the learning process outside the classroom provided numerous benefits even though they took longer time because of the coordination process. The practical learning that students accomplished to develop their knowledge had an effect on the entrepreneur community in the industrial center area. This is useful for advancing business or professional practice as a result of the involvement of all agents and elements that are systemic but complex [29]. A community has a specific purpose to gather a group of people who have the same goal. The learning carried out by students in the Sukaregang Garut West Java Industry center area indirectly became a place and site of learning that can contribute to improve life experiences, increase social capital, and can also facilitate other actions that are collectively beneficial [37]. As a result, learning outside the classroom like what had been proposed by the researchers is a real lesson that is very useful for students to increase their insight about ecopreneurship. Moreover, the results of the student interviews can be shared in each class so that all students understand and are expected to think about learning to initiate a new environment-based businesses.

The essential experiences that students achieved students in the workshops is expected to be informed and share to others. The information brought into ecopreneurship learning gives a fundamental understanding to all students in order to think, initiate and manifest ecopreneurship practically. So far, the efforts carried out by many entrepreneurs actually contributed significantly to economic growth both at the regional and national levels. This is certainly a tremendous achievement for talented entrepreneurs. However, one thing that still cross our mind is how a business or a large company deals with the problem of their industrial waste. Entrepreneurial activities intending to keep existing must consider and pay attention to sustainable entrepreneurship.

\section{CONCLUSION}

Entrepreneurship for environmental sustainability is needed in an era of protecting the environment to support future generations in meeting their own needs. Entrepreneurship that is based on environmental sustainability will last longer due to the absence of obstacles or negative implications of the business results for the community. Environmental sustainability-based entrepreneurship is closely related to entrepreneurial sustainability that both focus on the environment. Sustainable entrepreneurship focuses on preserving nature, life support, and communities to pursue opportunities in realizing future products, processes and services to benefit both economically and noneconomically for individuals and society.

By sharing the results of interviews with leather entrepreneurs and other students in the class, this research can provide an understanding and concrete examples of environmental-based businesses. Students are also expected to start thinking about new business opportunities that is profitable without being apathetic to environmental sustainability. Or even an idea emerged to treat industrial waste into a useful item that is worth to sell. Thus, students will consider their business, starting from the production process, marketing, and waste from their business products. The recommendation for university is to hold more workshops for students with the aim of enhancing students' insights to create insightful students and later be able to implement their knowledge and understanding in social life. Furthermore, the government is expected to assist and guide the difficulties of entrepreneurs in their efforts to process waste into useful and marketable products in order to reduce pollution in the community so that the environment can be maintained.

\section{CONFLICT OF INTERESTS}

The author has not declared any conflict of interests.

\section{REFERENCES}

[1] Avelino, F., \& Rotmans, J. (2011). A dynamic conceptualization of power for sustainability research. Journal of Cleaner Production, 19(8), 796804. https://doi.org/10.1016/j.jclepro.2010.11.012

[2] Schaper, M. (2002). The essence of ecopreneurship. Greener Management International, (38), 26-30. https://doi.org/10.9774/gleaf.3062.2002.su.00004

[3] Cohen, B. (2006). Sustainable_valley_entrepreneurial_ecosy20160723 -21349-wk9fj6. 14(March 2005), 1-14.

[4] Hockerts, K., \& Wüstenhagen, R. (2010). Greening Goliaths versus emerging Davids - Theorizing about the role of incumbents and new entrants in sustainable entrepreneurship. Journal of Business Venturing, 25(5), 481-492. https://doi.org/10.1016/j.jbusvent.2009.07.005

[5] Kuckertz, A., \& Wagner, M. (2010). The influence of sustainability orientation on entrepreneurial intentions - Investigating the role of business experience. Journal of Business Venturing, 25(5), 524-539.

https://doi.org/10.1016/j.jbusvent.2009.09.001

[6] Shepherd, D. A., \& Patzelt, H. (2011). The New Field of Sustainable Entrepreneurship: Studying Entrepreneurial Action Linking "What Is to Be Sustained" With "What Is to Be Developed." Entrepreneurship: Theory and Practice, 35(1), 137163. $\underline{6520.2010 .00426 . x}$ https://doi.org/10.1111/j.1540- 
[7] Outsios, G., \& Kittler, M. (2018). The mindset of UK environmental entrepreneurs: A habitus perspective. International Small Business Journal: Researching Entrepreneurship, 36(3), 285-306. https://doi.org/10.1177/0266242617739343

[8] Poldner, K., Shrivastava, P., \& Branzei, O. (2017). Embodied Multi-Discursivity: An Aesthetic Process Approach to Sustainable Entrepreneurship. Business and Society, 56(2), 214-252. https://doi.org/10.1177/0007650315576149

[9] Thompson N, Kiefer K and York JG (2011) Distinctions not dichotomies: Exploring social, sustainable, and environmental entrepreneurship. In: Lumpkin GT and Katz JA (eds)Social and Sustainable Entrepreneurship. Howard House: Emerald, pp. 205-233.

[10] Kirkwood, J., \& Walton, S. (2010). What motivates ecopreneurs to start businesses? International Journal of Entrepreneurial Behaviour and Research, $16(3)$, 204-228. https://doi.org/10.1108/13552551011042799

[11] Macalister, T. (2004) Wind reaper, The Guardian, September 18, p. 32.

[12] Dryzek, J. S. (1997) Politics of the Earth: Environmental Discourses (Oxford: Oxford University Press).

[13] Hajer, M. (1995) The Politics of Environmental Discourse: Ecological Modernisation and the Policy Process (Oxford: Clarendon Press).

[14] Beveridge, R., \& Guy, S. (2005). The rise of the ecopreneur and the messy world of environmental innovation. Local Environment, 10(6), 665-676. https://doi.org/10.1080/13549830500321972

[15] Isaak, R. (2002). The making of the ecopreneur. Greener Management International, (38), 81-91. https://doi.org/10.9774/GLEAF.3062.2002.su.00009

[16] Walley, E. E. L., \& Taylor, D. W. D. (2002). Opportunists, Champions, Mavericks . . . ? 31-43.

[17] Johnston, P., Everard, M., Santillo, D., \& Robèrt, K. (2007). Discussion Articles Reclaiming the Definition of Sustainability. Environmental Science and Pollution Research, 14(1), 60-66.

[18] Gigliarano, C., Balducci, F., Ciommi, M., \& Chelli, F. (2014). Going regional: An index of sustainable economic welfare for Italy. Computers, Environment and Urban Systems, 45, 63-77. https://doi.org/10.1016/j.compenvurbsys.2014.02.00 7

[19] Brown, A. L. (1994). The Advancement of Learning. Educational Researcher, 23(8), 4-12. https://doi.org/10.3102/0013189X023008004

[20] Porter, M. E., and Claas van der Linde. (1995) "Green and Competitive: Ending the Stalemate." Harvard Business Review 73, no. 5

[21] Banerjee, S., Carlin, B. P., Gelfand, A. E., \& Banerjee, S. (2003). Hierarchical Modeling and Analysis for Spatial Data. Hierarchical Modeling and
Analysis for Spatial Data, (January). https://doi.org/10.1201/9780203487808

[22] Koizumi, Y., Yamada, R., Nishioka, M., Matsumura, Y., Tsuchido, T., \& Taya, M. (2002). Deactivation kinetics of Escherichia coli cells correlated with intracellular superoxide dismutase activity in photoreaction with titanium dioxide particles. Journal of Chemical Technology and Biotechnology, 77(6), 671-677. https://doi.org/10.1002/jctb.619

[23] Henriques, I., \& Sadorsky, P. (1999). The relationship between environmental commitment and managerial perceptions of stakeholder importance. Academy of Management Journal, 42(1), 87-99. https://doi.org/10.2307/256876

[24] Jolink, A., \& Niesten, E. (2015). Sustainable Development and Business Models of Entrepreneurs in the Organic Food Industry. Business Strategy and the Environment, 24(6), 386-401. https://doi.org/10.1002/bse.1826

[25] Gast, J., Gundolf, K., \& Cesinger, B. (2017). Doing business in a green way: A systematic review of the ecological sustainability entrepreneurship literature and future research directions. Journal of Cleaner Production, $147, \quad 44-56$. https://doi.org/10.1016/j.jclepro.2017.01.065

[26] Djordjevic, B. (2013). Strategic entrepreneurship. Mediterranean Journal of Social Sciences, 4(15 SPEC.ISSUE), $127-135$. https://doi.org/10.5901/mjss.2013.v4n16p127

[27] Kelley, C. P., Mohtadi, S., Cane, M. A., Seager, R., \& Kushnir, Y. (2015). Climate change in the Fertile Crescent and implications of the recent Syrian drought. Proceedings of the National Academy of Sciences of the United States of America, 112(11), 3241-3246.

https://doi.org/10.1073/pnas.1421533112

[28] Cohen, B., \& Winn, M. I. (2007). Market imperfections, opportunity and sustainable entrepreneurship. Journal of Business Venturing, 22(1), 29-49. https://doi.org/10.1016/j.jbusvent.2004.12.001

[29] Ateljević, J., \& Trivić, J. (2016). Economic development and entrepreneurship in transition economies: Issues, obstacles and perspectives. In Economic Development and Entrepreneurship in Transition Economies: Issues, Obstacles and Perspectives. $\quad$ https://doi.org/10.1007/978-3-31928856-7

[30] Rastogi, P., \& Sharma, R. (2018). Ecopreneurship for sustainable development: The bricolage solution. Handbook of Engaged Sustainability, 2-2, 991-1016. https://doi.org/10.1007/978-3-319-71312-0 46

[31] Kasimu, S., Peter, T., \& Peter, T. (2018). Sustainable entrepreneurship intention among university students in Uganda: A conceptual paper. African Journal of Business Management, 12(6), 131-139. https://doi.org/10.5897/ajbm2017.8447 
[32] Dean, T. J., \& McMullen, J. S. (2007). Toward a theory of sustainable entrepreneurship: Reducing environmental degradation through entrepreneurial action. Journal of Business Venturing, 22(1), 50-76. https://doi.org/10.1016/j.jbusvent.2005.09.003

[33] Gliedt, T., \& Parker, P. (2007). Green community entrepreneurship: Creative destruction in the social economy. International Journal of Social Economics, $34(8)$,

$538-553$.

https://doi.org/10.1108/03068290710763053

[34] Kemmis, S. (2006). Participatory action research and the public sphere. Educational Action Research, 14(4), 459-476. https://doi.org/10.1080/09650790600975593
[35] Ståhlbröst, A., \& Bergvall-Kåreborn, B. (2011). Exploring users motivation in innovation communities. International Journal of Entrepreneurship and Innovation Management, 14(4), 298-314. https://doi.org/10.1504/IJEIM.2011.043051

[36] Jucevičius, G., \& Grumadaitè, K. (2014). Smart Development of Innovation Ecosystem. Procedia Social and Behavioral Sciences, 156(April), 125129. https://doi.org/10.1016/j.sbspro.2014.11.133

[37] Le, A. T. P. (2018). The contributions of community learning centres (CLCs) to personal and community development in Myanmar. International Review of Education, 64(5), 607-631. https://doi.org/10.1007/s11159-018-9721-2. 